\title{
DISSENTERS' RIGHTS AND CORPORATE SURVIVAL: A RE-EXAMINATION OF SOME REDEMPTION STATUTES
}

STATE statutes in most jurisdictions permit corporations chartered for a limited period ${ }^{1}$ to extend their business life 2 by amending the article

1. A number of states still limit all corporation charters to a stated number of yoar. Such provisions "are an unfortunate survival of early restrictions supposed to prutset the public against abuses." B.lluntrive on Corporations $\$$ 33, p. 97 (2d ed. 1946). See also id. at $\$ 308$, pp. 717-18.

Limiting provisions are found in the following jurisdictions: Mrra. Co:ssr. Art. XII. \$ 3 (30 years) ; ArIz. Cone ANx. \$ 53-304 (1939) (25 years); GA. Cone A:a:. \$ 22.802 (Supp. 1951) (35 years) ; Rev. Laws HawaII $\$ \$ 309$ (1945) (50 years); KA\%. GE*. STAt. c. 17, $\$ 2 S 02$ (1949) (100 years): MIss. Core AxN. \$ 5310 (1950 Surp.) (9? years); Mont. Rev. Stat. tit. 15, $\$ 10 \$$ (1047) (10 years): N.M. Strt. A:7.. c. 54. $\$ 202$ (1941) (100 years); OnL. STAT. Axx. tit. 1S. \$1.14 (Cum. Sunp. 1952) (\$0 years) ; Texas Rev. Civ. Stat. $\$ 1320$ (1925) (\$0 ytars); Utan Cost. Axis, tit. 18, c. 2. $\$ 5$ (1943) (100 years); Wyo. Conp. St.1T. Axx. c. H. $\$ 101$ (1945) (\$0 years).

Even in states where most corporations can obtain unlimited charters, certain tyl 1 s: of corporations have a restricted life period. E.g., Kr. KEv. Sr.1T. c. 273, \$130 (1949) (50 years for cooperative marketing associations) : Mass. Ax:. Liws c. 15f, $\$ 7$ 193?, (50 years for real estate corporations).

2. The terms "extension statute," "revival statute" and "renewal statute" are variously used by courts, legislators, and commentators tu deacribe two tyes of laws: first, laws which authorize an existing corporation to lengthen its clurter; sccond, law: which authorize a corporation which is carrying on business onerations, but which hat let its charter expire, to revive it. Statutes of the second tyre onurats retrouctively to give the corporation uninterrupted legal existence. For further clacsification, ses 8 Fletcher. Cyclopenda of Corporation Law $\$ 1092$ ( ferm. cd. 1931). For statutes s\$: Corporation Mianual, Class. 10 (1952).

Statutes of the first type are found in the following states: Ala. Corr Asi:. tit. 10, \$ 18 (1940); Arrz. Code Ann. \$ 53-304 (1939); ARk. St.1T. Axz. \$ 64-107 (1947); Calif. Corp. Code ANx. \$ 3700 (Supp. 1951); Cinn. St.rt. Axw. c. 41, \$ 53 (1935);

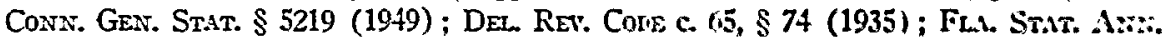
$\$ 612.5$ (1943); GA. Cone ANn. \$\$ 22-1814, 22-1825 (1933); HAwni Rr. Cons \& 1814 (1945) ; Idaho Cone $\$ 30-146$ (1947) : Sirth-Hunn Ill. Axi. Stat. c. 32, \$ 157.52 (1935) ; Ind. Stat. ANn. \$ 25-221 (Burns 194\$); Iow Cots Az*2. \$\$ 491.20, 491.25 (1946) ; Kan. Gex. Stat. Axn. c. 17. \$ 4301 (1949); Ky. Rex. Sr.1т. . 1:a:. c. 271, \$ 445 (1948) ; LA. Rev. Stat. tit. 12, $\$ 2$ (1950) ; Mr. Axx. Cors tit. 23, $\$ 10$ (Flacl: 1951);

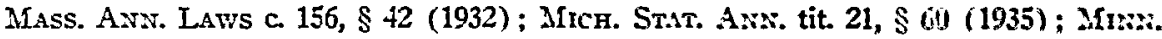
Stat. Axn. \$ 300.13 (1946); Miss. Cone Axx. \$ 3323 (1942); Mo. Srat. A:za. B 351.085 (Vernon's 1951) ; Movt. Rer. Cones tit. 15, \$\$ 216, 223 (1947); \En. RE:. StaT. \$ 21-1126 (1943) ; Nex. CMMr. L.aws Axx. \$ 1092 (1929); N.H. Rev. L.2WS c. 274, $\$ 40$ (1942) ; N.J. Rev. Stat. tit. 14. c. 11, \$\$ \$-12 (1937); X.M. Sr.at. Azt. \$ \$t-220 (1941) ; N.Y. GeN. CoRp. Law \$ 45; X.C. Gex. Star. Axs. c. 55, \$ 31 (1943); N.D. Rev. Cone $\$ 10-0214$ (1943) ; OkLt. Stat. ANN. tit. 18, \$ 1.151 (Cum. Supp. 1952); Ort Consp. Laws ANN. $\$ 77-260$ (1940); P. Hes. Comp. Act. $\$ 801$ (1933); R.I. Gr:i. LAws c. $111, \S 50$ (1938) ; S.C. Cons ANx. $\$ \$ 7743,7717$ (1942); S.D. Corc $\$ 11-0201$ (1939); Tenn. Cone Ann. tit. 9. \$ 3720 (1934); Tex. Str.t. Rev. Civ. \$ 1315(a) (1925) ; UTAH Code Axx. tit. 18, c. 2, \$ 44 (1943); Vt. \$r.1r. \$ 5705 (1947); VA. Code AnN. tit. 13, \& 35 (1950); Wash. Rev. Stat. Axx. tit. 25, $\$ 3803-37$ (Supp. 
of incorporation. ${ }^{3}$ These statutes ${ }^{4}$ reflect legislative recognition of the value of long-term corporate existence. ${ }^{5}$ Before the enactment of extension provisions, corporations about to expire could dissolve and re-incorporate. ${ }^{0}$

1940); W. VA. Code Ann. $\$ 3017$ (1949); Wis. Stat. c. 180, $\$ 50$ (1951); Wro. Conp. STAT. ANN. c. $44 \S 101$ (1945).

Statutes of the second type are found in the following states: Ariz. Laws 1951, c. 89, \& 1; Calif. Corp. Code ANn. $\$ 3700$ (Supp. 1951); Colo. Strt. Ann. c. 41, $\S 58$ (1935); Det. Rev. Code c. 65, § 74 (1935); GA. Code ANn. \& 611-2 (1933); KAN. Gen. Stat. Ann. c. 17, § 4301 (1949); Ky. Laws 1952, S.B. 84; LA. Rev. Stat. tit. 12, § 42 (1950); Mich. Stat. Ans. tit. 21, § 61 (1935); Minn. Laws 1945, c. 201; Miss Laws 1950, c. $308 \S \S 3,4$; Mont. Rev. Codes tit. 15, § 216 (1947); Neb. Rev. Stat. § 21-1126 (1943); Nev. Colup. Laws Ann. \& 1692 (1929), amended, Nev. Laws 1937, c. 5; N.J. REv. StAT. tit. 14, c. 11, \$ 11 (1937); N.M. Stat. Ann. \$ 54-222 (1941); N.Y. Gen. Conp. Law \& 49; N.C. Gen. Stat. ANN. c. 55, § 32 (1943); N.D. Rev. Code $\S 10-0217$ (1943); Okla. Stat. Ann. tit. 18, § 1.172 (Cum. Supp. 1952); Ore. Comp. Laws ANn. § 77-249 (1940); S.C. Code Ann. $\$ 7743$ (1942); S.D. Laws 1950, c. 1; Tex. Stat. Rev. Civ. $\S 1315$ (1925); VA. Code AnN. tit. 13, § 77 (1950). See also Revizial of Corporafc Lifc After Expiration of Corporate Charter in REPORT OF N.Y. LAw REvision Coms. 365-408 (1943).

Some states distinguish between renewals of the corporate charter, which lead to another limited period of existence, and amendments, which result in authority for perpetual life. See, e.g., Iowa CoDE ANN. $\S 8491.20,491.25$ (1946). See also note 30 infra.

The few states which permit only perpetual incorporations today generally make provision for extension of existing limited corporations. E.g., CALIF. CORP. CodE ANN. $§ 301$ (1947).

In this note, the term "extension statute" will be used to refer to both types of laws, since the practical effect on stockholders is the same in either situation.

Corporations which have reached the end of their chartered life are considered dissolved as a matter of law. In a number of states, however, statutes give such corporations certain powers, such as the power to sue and be sued, and authority to wind up the corporate affairs. E.g., N.Y. Gen. Corp. Law \& 29. See Ballantine on ConpoisTrows $\$ 33$ (2d ed. 1946). Some courts have held that corporations continuing to exercise corporate powers after charter termination are de facto corporations. Brady v. Del. Mut. Life Ins. Co., 2 Del. 237, 45 Atl. 345 (1899) ; Hall v. Kimsey, 48 Ga. App. 605, 173 S.E. 437 (1934). The authority of such corporations can only be questioned by the state, 8 Fletcrier, Cyclopedia of Corporation LAw $\$ \$ 3842-3343$ (perm. ed. 1931).

3. Usually a majority of stockholders must authorize extension. Sec, co., N.Y. GiN. CoRp. Law $\$ 45$. Some statutes require a $3 / 4$ vote of stockholders. E.g., Akiz. Cone

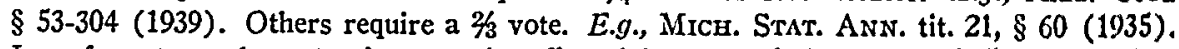
In a few states the extension may be effected by vote of the board of directors. E. . . N.D. Rev. Code $\S 10-0214$ (1943). See 8 Fletcher, Cyclopedia of Corporation law $\S 4097$ (perm. ed. 1931).

4. See note 2 supra.

5. Early corporate charters were limited because of public distrust of the corporate device. See Berle \& Means, Modern Corporations and Private Property 130-3 (1932). But 19th century technological developments required increasingly large investments in fixed assets for successful industrial survival. Thus relative permanence of business enterprises became a virtual necessity.

6. Reincorporation was assured only under general incorporation statutes. If all shareholders in the old corporation desired to reinvest, the corporation still might have 
But to maintain assets unimpaired, all stockholders had to reinvest. If some stockholders objected, the enterprise was forced either to obtain new investment, curtail operations, or cease business entirely. Extension statutes, on the other hand, allow charter renewal without impairment of capital whenever a required number of stockholders approve, ${ }^{7}$ despite the objections of a dissenting minority.

Several states also provide that minority stockholders who oppose extension may withdraw from the corporation and have their shares redeemed. ${ }^{6}$ This procedure ${ }^{9}$ may be particularly advantageous for shareholders in closely-

faced the problem of retaining its old and perhaps valuable name. Some statutes provide no safeguards to prevent another firm from usurping the name in the lintus between dissolution and reincorporation. 6 Fletcher, Cychopenia of Conforanto: LAW $\$ 2416$ (rev. ed. 1950).

7. See note 3 supra.

8. IDAHO CODE $\$ 30-150$ (1947); Iowa Cone Axx. $\$ 491-25$ (1946); L.1. Rev. Sr.nT.

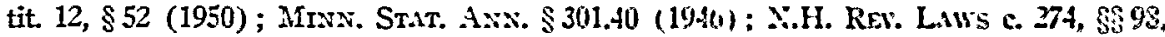
40, 75 (1942); OrLa. Stat. Ann. tit. 18, § 172 (Cum. Supp. 1952); Wash. Rer. Stat. Ans. tit. 25, \$3\$03-41 (Supp. 1940). See alsu Mfouer. Ers. Conp. .ICT, 9 C.L.A. \$ 42.

The 1947 Oklahoma statute gave dissenting stochholders a right of redemption whenever the corporation "substantially changed the period of existence" OnLr. Srst. Arsi. tit. $18, \S 157$ (Cum. Supp. 1952). Section 172 gave the same right unon a revival of an expired corporation. See note 2 stpra. In 1949, the redemption provision of \& 157 was repealed. Okla. Laws 1949, § 12, p. 122. See also Vliet, The Ollahoma Busiress Corporation Act II, A Strriey. 3 OkLl. L. Rev. 269, 289 n.12S, 297-S (1950).

Charter extension is only one situation in which redemptive rights have bisn grantel to dissenters. More typically these include consolidations, mergers and sale of th: corporate assets. See in general Note, 38 V.. L. Rer. 915 (1952).

Three recent cases deal with the problem of redemptive rights for dissenters to charter extensions. Two-Melsha v. Tribune Pub. Co., 243 Iowa-, 51 N.W. 24423 (1952); State $c x$ rel. Robbins v. Shellsburg Grain \& Lumber Co., $2+3$ Iuwa-, 53 X..h". 2d 143 (1952)-involved construction of Iuwh Cone Axs. $\$ 491.25$ (1946). Sce also Terrell v. Ringgold County Mut. Tel. Co., 225 Iowa 994, 232 N.W. 702 (1938), 48 Yale L.J. 1450 (1939). The third case, Garzo v. Jlaid of the Mist Steamboat Co., 303 N.Y. 516, 104 N.E.2d $8 S 2$ (1952), affirming 105 N.Y.S.2d 4 (1951), 36 Mrs:. L. Rev. 267 (1952), arose in a situation where there was no applicable redemption statute. Defendant corporation had inadvertently permitted its charter to expire, but later availed itself of N.Y. Gex. Cosp. LAW $\$ 49$ which authorized "revival" of expired corporate charters. Plaintiff sought payment on the ground that title to the corporate assets had vested in the stockholders at the time of charter expiration and that the legislature had no power to interfere with such vested property rights. However the cuurt, per Fuld, J., denied his contention, holding that under the "revival" statute the corlorate charter was extended as of the original expiration date su that the stostholders never acquired a vested property interest in the corporate assets.

Doctrinally the Garzo case involves different problems irum casus arising undur extension statutes. Functionally, however, the impact uf extension on stodiholder rights is the same whether voted before or after the end of the original charter leriul. Therefore, evaluation of the desirability if redemption rights involves the same pulicy considerations in either case.

9. Redemption statutes normaliy cover the situations in which the curgoration must purchase dissenters' shares. Appraisal statutes supplement redemption statutes by setting 
held corporations, since the market price of their shares ${ }^{10}$ is often below the amount obtainable by statutory payment. ${ }^{11}$ However, stuch redemption statutes may frustrate the policy of the laws permitting charter extension. An enterprise which has few funds beyond its immediate business needs will be forced to use working capital to pay off dissenting stockholders. ${ }^{12}$ It may then find it impossible to continue operations, at least, without a major reorganization. ${ }^{13}$ Similarly, a corporation approaching the termination of its

out procedures for determining the price at which redemption must be made in casse the parties do not agree. For a thorough discussion of appraisal statutes, sec Note, 60 YALE: L.J. 337 (1951). This type of redemption should be distinguished from provisions authorizing routine redemption of shares at prices contracted with stockholders.

In order to qualify as a dissenter to corporate action, prescribed procedures must be strictly followed. A typical statute is WASH. Rev. STAT. ANN. § 3803-41 (Supp. 1940), which defines a dissenting stockholder as one "who did not vote in favor of such corporate action, and who, within 20 days after notice ... of the meeting . . . filed with the corporation his written objection to such corporate action, demanding payment for his shares." See also MinN. STAT. ANn. $\$ 301.40$ (1946) (dissenting stockholder must file written objection before meeting); IowA CODE ANN. § 491-25 (1946) ("the right [of redemption] exists for those who vote against the renewal"). For a discussion of the inadequacy of this language, see SEC, REPORT of THE STUdY AND INVESTIGATION Or tHe Work, Activities, Personnel and Functions of Protective and Reorganization Comairtees, pt. VII, app. B, 598-600 (1938).

For excellent general coverage of dissenters' rights upon corporate changes see Dodd, Dissenting Stockholders and Amendments to Corporate Charters, 75 U. oF PA. L. Rev. 585, 723 (1927) ; Levy, Rights of Dissenting Stockholders to Appraisal and Payment, 15 CORNELL L.Q. 420 (1930).

10. Frequently, there is no readily avilable market for the stock of a closely-held corporation. See Winer, Proposing a New York "Close Corporation Law," 28 Conneu. L.Q. 313, 314 (1943). There is no precise definition of a closely-held corporation; but, in general, the term indicates a small corporation or one with few stockholders. See Israels, The Close Corporation and the Law, 33 CoRnelr L.Q. 488 (1949).

11. There are various statutory verbal yardsticks for determining the amount of redemption payment: "[T]he value of ... shares as of the date of the authorization of such corporate action with interest thereon . . . from such date" (P-HI WASir. CoRp. SERv. 38 (1952) ); "the fair cash value of ... shares as of the day before such vote [for extension] was taken" (LA. REv. Stat. tit. 12, § 52 (1950)); "will purchase at its real value" (Iowa CODE ANN. $\S 491-25$ (1946) ). For attempts to give specific content to these standards, see Notes, 16 BrookLy L. Rev. 86 (1949), 40 CALif. L. Rtw. 140 (1952).

12. The larger the minority, the greater the likelihood of injury to the corporation. Blindly facilitating such a situation, a Louisiana redemption statute provides that dissenters may demand redemption only when the majority does not equal $80 \%$ of the voting stock. LA. Rev. StaT. tit. 12, \& 52 (1950). Thus a corporation is not required to pay when there are few dissenters and it could probably do so without financial injury. But redemptions may be sought by a larger minority, whom the corporation may be unable to pay.

The Louisiana statute may also lead to unusual results in other cases. See Herriques v. Vaccaro, 218 La. 1020, 56 So.2d. 236 (1951).

13. See, e.g., Warnock Co. v. Hudson Mfg. Co., 200 Minn, 196, 273 N.W. 710 (1937) (defendant corporation was required to redeem dissenters' shares upon extension 
charter may be forced to cancel expansion programs in order to meet possible stockholder demands. Thus, even though most redemption statutes forbid payments which leave the corporation with less assets than liabilities, 14 the exercise of redemptive rights can seriously impair business operations.

The principal justification for redemption statutes is that they protect dissenting stockholders from injury. ${ }^{15}$ But in the absence of such a statute, charter extension inflicts only illusory damage on a dissenting shareholder. ${ }^{16}$ Unlike a merger or consolidation, which results in a different capital structure, extension does not alter a stockholder's relative rights in the corporation. Therefore his alleged injury can occur only if the market price of his stock is below liquidation value. Even when this is true, however, the stocliholder probably was not induced to purchase his shares by the expectation that dissolution would take place on a fixed date. Had subsequent repayment been a significant factor, he more likely would have invested in safer risks such as bonds or savings accounts. And, if the stockholder had actually relied at any time ${ }^{17}$ on the expiration date in the corporate charter, his expectation

of the charter). Apparently, the action of dissenting stochholders in seeling redemption payments forced the majority to petition for dissolution of the corporation. See Radanough v. Hudson MIfg. Co., 212 Minn. 1S0, 2 N.W.2d S2S (1942).

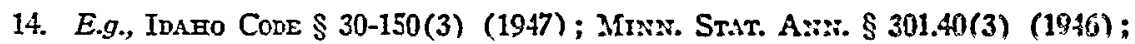
Orza. Stat. Ann. tit. 18, $\$ 1.161$ (g) (Cum. Supp. 1952); Wash. Rer. Srar. Azzz. $\$$ 3803-41 (III) (Supp. 1940). Louisiana and New Hampshire would probably achieve the same result under their general provisions on payments to stedholders: LA. Rew. Stat. tit. 12, $\$ 26$ (1950); N.H. Rev. Laws c. 274, $\$ 100$ (1942).

For a description of the rights of creditors to prevent redemption payments which render a corporation insolvent, see Levy, Rights of Dissenting Shardholders to Apfraisal and Payment, 15 CORNenc L.Q. 420, $431-3$ (1930).

15. See Lattin, $A$ Reappraisal of Appraisal Statutes, 38 Mrca. L. Rev. 1165, 1182 (1940) ; Levy, supra note 14, at 421. It has been suggested that another justification for redemption statutes is that by providing for payments to dissenters, they eliminate litigation which might otherwise delay or make impossible beneficial corporate change. Lattin, Remedies of Dissenting Stockholders Under Appraisal Statufes, 45 Harv. L. REv. 233, 237 (1931). But in extension situations, where the corporation is damaged when forced to redeem dissenting shares, redemption statutes harm rather than help the corporation.

For an excellent discussion of redemption statutes, see STarexs, Consoantuns 539-91 (2d ed. 1949).

16. Miost authorities favoring redemption statutes in cases uf curpurate estension have failed to examine adequately the question of injury to dissenting stocliholders. Sce 1944 Public Papers of Governor Dewey 248 (1945); Nutes, 48 Yale L.J. 1455 (1939); 37 MrNN. L. REv. 267 (1952); 19 ST. JoHAr's L. Rev. 72, 74 (1944); for a brisi reference to the problem, see Ballantine \& Sterling, l'psething Mergers asd Consulidations: Alternatize Rentedies of Dissenting Sharcholdors in Culifornia, 27 CALIF. L. RE. 644, 672 (1939).

17. Reliance on the charter limitation could occur in thrce situations: (a) where the prospect of future dissolution was the subjective mutivation for purchase; (b) where reliance began after purchase, because of the charter provisions; (c) where dissolution at a fixed time was bargained for and the promise to dissolve was included in the purchaser's contract. Only the third possibility, if it should ever uccur, deserves pro- 
would have been unjustified. Charter time limits, required by statute, imply no promise by the other stockholders to vote against an extension. Even if the corporate charter should antedate the extension statute, such charters, unlike ordinary contracts, are subject to almost unlimited amendment by the legislature. ${ }^{18}$ Thus the possibility of a legislatively authorized extension was included in the stockholder's original risk.

A stockholder may also feel injured if forced to remain in a corporation which later suffers financial loss. But he cannot complain that he is an unwilling participant, for that is merely another way of saying his desire for liquidation has been defeated. In essence he is in no different position than he would have been had the majority voted against dissolution under any other circumstances. ${ }^{19}$ Like other stockholders, therefore, he must either sell out or bear losses which result from the ordinary risks of the business. Only if the majority for private reasons-as, for example, to maintain their managerial salaries-voted an extension when such action would clearly damage the corporation, would the minority stockholders suffer a recognized wrong. Under existing case law, however, a remedy already exists. ${ }^{20}$ Minority stockholders can attack the majority's action as a breach of their fiduciary duty. ${ }^{21}$ There appears no adequate reason for making redemption

tection in a hard-boiled world which normally does not enforce individual expectations unless induced by contractual promises. However, in the unlikely event the third sittution should ever arise, the stockholder would appear to have a remedy even in the absence of a redemption statute. He would have either a contractual action for damages, against the seller of the stock, or perhaps even a contractual action to force dissolution.

18. Existing law almost everywhere now recognizes that the legislature may, by use of its reserved power to amend and repeal corporate charters, permit less than a unanimous number of stockholders to make corporate changes, although the corporation may have been chartered before passage of a law authorizing such change. Stuch a law is not invalid as denying the vested rights of dissenting stockholders even if unaccompanied by a redemption statute. Ballantine, Corporatrons $\S 290$ (2d ed. 1946). But even where the courts still talk in terms of vested rights of shareholders, and invalidate statutes seeking to permit such corporate changes, extcnsion statutes have been upheld as creating only a non-fundamental change, so that the courts never reach the question of vested rights. Drew v. Beckwith, Quinn \& Co., 57 Wyo. 140, 114 P.2d 98 (1941); and cases collected in Note, 108 A.L.R. 62 (1937). Contra: Pratt v. Pueblo Building \& Loan Ass'n, 1 Colo. Nisi Prius D. 171 (1902). See 13 Fletcher, Cyclopedis of CORPoration LAw $\$ 5776$ (rev. ed. 1943). For discussion of the constitutional issues, see Dodd, Dissenting Stockholders and Amendments to Corporate Charters, 75 U. of PA. L. Rev. 585 (1927); Note, 13 U. of Pitr. L. Rev. 723 (1952).

The so-called "revival" státutes have also been held constitutional. Loeffler v. Federal Supply Co., 187 Okla. 373, 102 P.2d 862 (1940); Comment, 28 Calif. L. Rev. 194, 201 (1940). See note 2 supra.

19. See SEC, op. cit. supra note 9, App. A, at 478 n.47.

20. See, e.g., Cooperative Milk Serv. v. Hepner, 81 A.2d 219, 224 (MId. Ct. of App. 1951) ; Stevens, Corporations $\S 126$ (2d ed. 1949).

21. Recovery in an action for breach of a fiduciary duty may be difficult, for the minority stockholders must prove that the majority acted fraudulently or in bad faith. Stevens, Cokporations $\$ 126$ (2d. ed. 1949). But it is impractical to seek a solution 
an additional remedy merely because a corporate extension was the framework in which the breach was committed.

Even where redemptive rights exist, the stockholder's opportunity to protect himself against the risk of future corporate losses occurs only fortuitously. States which limit corporate life still permit incorporation for extended periods without regard for the economic life of the particular business." . And incorporators fix time limits in charters only from statutory necessity. 23 Thus, ability of a minority to force partial liquidation at the moment of charter extension appears more nearly a windfall than the result of any calculated attempt to protect dissenters from a genuine injury.

Of the states providing redemption rights, ${ }^{24}$ only one has sought also to protect the corporation from injury. In Iowa, a statute provides that majority stockholders rather than the corporation shall purchase the shares of a dissenting minority within three years of a vote to extend.95 In a recent case, the Iowa Supreme Court was asked to force a corporate dissolution after

to the problem of proof by blanket redemption rights for all corporate action to which a stockholder objects, for this would undermine corporate stability. Nor is there any reason to provide a redemption remedy in any specific corporate siturtion unless the risk and the extent of loss is large.

22. One writer states that many businessmen do not make investment forceasts much over five years in the future. Kunsmes, Deprecintron Polici asio Postwar ExPANSION 39 (1946).

Of the states granting redemption rights for charter extension, only Ol:lahoma still specifically limits corporate existence to a term of years. OrIs. STAт. A:z:. tit. 18, § 1.14 (Cum. Supp. 1952) (formerly 20 years, amended to 50 years in 1949). Li. Consr. Art. XIII, $\S \&$ (1921) prohibits perpetual incorporation, but incorporation statutes set no definite charter limitations. LA. REv. STAT. tit. 12, $\$ \S 3(2), 12(2)$ (1950). In the remaining states incorporation may be perpetual. InaHo Cure $\$ 30-114$ (1947) (adogted Idaho Laws 1929, c. 262, $\$ 10$, p. 545). IowA Cone A.s:. $\$ 491.24$ (1946) (adopted Iowa Laws 1943, 50 G.A., c. 225, § 5); Minz. St.t. Awr. $\$ 301.04$ (1946) (adonted Minn. Laws 1933, c. 300, $\$ 3$ ) ; N.H. Rev. Laws c. 274, $\$ 4$ (1942) (first appearing X.H. Gev. Stat. c. CXXXIII. \$3 (1867)): Wash. Kex. St.1t. A:N. tit. 25, \$3803-11(b) (Supp. 1940) (adopted Wash. Laws 1933, \$11, p. 7781.

23. In states permitting incorporations for perpetual as well as limited duratiun, almost all present incorporations are for an unlimited prriod. Communieations to the Yale Law Jocknal from Mr. Frederic S. Hoffer, Jr., Corpuration Esaminer, Stat: of Connecticut, dated Sept. 24, 1952; from Mr. Sidney B. Gordun, Deputy See'y of Stats, State of New York, dated Sept. 23, 1952; from Margaret S. Storey, Director Corpuration Dept., Dept. of State, State of Delaware, dated Sept. 24, 1952, all un file in lale Law Library.

24. See note 8 supra.

25. "Stockholders voting for renewal shall have three years from the date such action for renewal was taken in which to purchase the stock voted against the renewal." IowA CONE A:NN. \$ 491-25 (1946).

Technically, the Iowa provision is not a "redemption statute" since it provides for purchase of dissenting shares by the majority rather than for actual redemption of the stock by the corporation.

26. State ex rel. Robbins v. Shellsburg Grain \& Lumber Co., 243 Iowa _-, 53 N.W.2d 143 (1952). 
majority stockholders had failed to purchase the dissenting shares within the allotted time. The court, in an effort to avoid injury to the corporation, 27 decided, contrary to the apparent meaning of the statute, ${ }^{28}$ that the minority's only remedy was against the majority as individuals. ${ }^{29}$ Thus the validity of the extension did not depend upon the majority stockholders' payment. Even so interpreted, however, the Iowa law may defeat the policy underlying extension provisions should majority stockholders abandon a planned extension because of an unwillingness or an inability to buy out dissenters..$^{30}$

In order to protect the corporation completely, a redemption statute must necessarily provide that payments be made only out of funds not required in the business. But such a provision would not offer effective relief to dissenting stockholders. Corporations could avoid payment though dividend policy or by cataloguing available funds as special reserves. ${ }^{31}$ Therefore, to

27. 53 N.W.2d at $145-6$.

28. The statute states: "Corporations . . . may be renewed . . . if those voting for such renewal will purchase ... the stock voted against such renewal." IOWs CODE ANN. $\S 491.25$ (1946). See also [1919-20] Ops. ATT'Y GEN. of Iows 448, where the Attorney General concludes that valid renewals depend upon the purchase of dissenting shares. The ruling was made on a previous version of the statute. See also Note, 48 Y ILE L.J. 1450,1453 (1939), where it is assumed that the validity of an extension under this statute depends upon payment.

The court in the Shellsburg case interpreted plaintiff's argument as requiring forfeiture of the corporate charter every time dissenters had not been paid within threc years following a charter extension. If renewal were voted more than three years prior to expiration of the original charter, the court reasoned, failure to pay dissenters would terminate the charter before the end of the original period of incorporation under the plaintiff's interpretation. The court rejected this result as absurd and concluded that payment is not a condition necessary for renewal. But the reasoning appears fallacious. If the majority had not bought the minority's shares within three years, the cricusion could be held void. Then the corporation's charter would continue as if no extension attempt had been made.

29. The actual point before the court was whether a quo warranto proceeding could be maintained. But the effect of the decision is to leave plaintiff to his personal action against the majority.

30. The majority apparently may avoid the consequences of $\S 491.25$ by amending the corporate charter to permit perpetual existence under $\$ 491.20$. In Melsha v. Tribune Pub. Co., 243 Iowa - 51 N.W.2d 425 (1952), the corporation rescinded a resolution extending the corporation under $\$ 491.25$, and subsequently utilized the alternative procedure. The plaintiff, who dissented from the extension, sought a declaratory judgment that he was entitled to have his shares purchased. The court denicd his claim on the ground that the parties had no adverse interest in the legal sense, since the corporation was under no obligation to purchase the shares in any cvent, and the majority stockholders had not been joined. However, the court also appeared to accept the theory that no payment to the minority was necessary since the extension was accomplished under $\$ 491.20$.

31. The minority would have difficulty showing that reserves were not for a legitimate business purpose. For analogous difficulties which arise in the proof of unreasonable accumulation of profits under INT. REv. CoDE § 102, see Koma, Inc. v. Comm. of Int. Rev., 189 F.2d 390 (10th Cir. 1951). 
determine whether they had a redemption right, dissenters might he forced to undertake a prohibitively expensive analysis of the corporation's position. 8 a

Redemption statutes do not effectively serve the conflicting goals of paying the minority and at the same time promoting corporate stability. Mihen the limited injury which extension can cause a dissenting minority is balanced against the disruption of corporate business that may result from redemption payments, such legislation appears unwarranted. Repeal of existing statutes is therefore desirable.

32. On the expense of appraisals, see Note, 60 Yale I.J. 337 (1951); see also N.Y. Stock Conp. Law \$21; Matter of Marcus, 273 App. Div. 725, 79 N.Y.S.2d 76 (1st Dep't 1948), aff'd without opinion, 303 N.Y. 711, 103 N.E.2d 338 (1951), 65 H.nns. L. REv. 1234 (1952). A determination of the corporation's ability to malie redemption payments cut of funds not essential for the corporate business would require not only an appraical of the value of the corporate assets and future earning probabilities-the determination made when the inquiry is the value of the corporate stock-but in addition a determination of expansion requirements in the light of business conditions, future replaceneent custs, and contingencies. 